\title{
The Chilean pension reform: 25 years later
}

Received (in revised form): 6th March, 2007

\section{Mauricio Soto}

is a senior research associate at the Center for Retirement Research at Boston College. He received a BS in Industrial Engineering (1998) from La Universidad de Los Andes in Colombia, an MBA (1999) and an MA in Economics (2000) from Texas Tech University. He is currently finishing a PhD in Economics at Boston College (2007).

Abstract A quarter of a century ago, Chileans embarked on a course of reform to modernise their economy. As part of these reforms, the Chilean government replaced the traditional pension system with one based on private retirement accounts. The radical reform, which brought dynamism to the Chilean economy, was a solution to the chaotic nature of the old system. The pension reform replaced the old pay-as-you-go-system with one pre-funded with personal retirement accounts. The Chilean experience illustrates that, when needed, extreme and fiscally sound pension reforms can bring dynamism to the capital markets. The system is, however, not perfect. Various measures of pension coverage suggest that the system is far from universal; commissions, although declining, still eat a significant piece of the retirees' accounts; the amount of workers projected to depend on the minimum pension guarantee or the assistance pension raises concerns about the fiscal consequences of the system.

Pensions (2007) 12, 98-106. doi:10.1057/palgrave.pm.5950049

Keywords: pension reform, Chile, social security and public pensions

\section{Introduction}

In 1980, the Chilean pension system was in crisis. It was paying more in benefits than it was receiving in contributions, and the projected actuarial imbalance was greater than the country's Gross Domestic Product (GDP). ${ }^{1}$ The prescribed solution was to radically transform the traditional pay-as-you-go structure to a system based on personal retirement accounts. Box 1 describes the main features of the current Chilean system. Nearly 25 years after the reform, it is possible to assess the Chilean experience.

\section{The good}

The pension reform replaced the old pay-as-yougo-system with one pre-funded with personal retirement accounts. The Chilean experience

Correspondence: Mauricio Soto, Center for Retirement Research, Boston College, 258 Hammond Street, Chestnut Hill, MA 02467-3808, USA Tel: + 16175521762 ;

Fax: + 1617552 0191;

Email: mauricio.soto@bc.edu illustrates that, when needed, extreme and fiscally sound pension reforms can bring dynamism to the capital markets.

\section{Enormous problems justify complete restructuring}

The traditional Chilean system was chaotic and vulnerable to political pressures. The 'system' was nothing more than a collection of more than 100 different pension regimes. Each regime had special rules, demanded different levels of contributions and promised different benefits, tailored to satisfy special interest groups. In some cases, white-collar workers could comfortably retire in their 40s, while blue-collar workers had to wait until their 60 s to qualify for minimum retirement benefits. The contribution rate reached levels that discouraged participation and compliance. In the mid-1970s, for example, average contribution rates surpassed 20 per cent of taxable wages. The system was poorly administered and inefficient. ${ }^{5-7}$ 
Chilean workers contribute about 12.5 per cent of their wages to the old age, disability and survivorship programme. Nearly 80 per cent of the employee's contributions go towards personal accounts which are administered by privately owned pension management institutions; the remainder pays for disability and survivorship insurance (7 per cent), administrative fees and commissions (13 per cent).

Net contributions are accumulated in private accounts and earn investment returns. Workers choose who they want to administer their private retirement account. Investment choices are restricted to five investment funds. ${ }^{2}$ Among these funds, the default choice depends on the age of the worker, so that younger workers are assigned to a fund with more risk exposure than older individuals.

Chilean private retirement accounts do not allow withdrawals before retirement. All workers can access their account if they reach the normal retirement age ( 65 for men, 60 for women). To qualify for early retirement, account balances must be large enough to generate an income stream that (1) replaces more than half of past earnings and (2) is greater than the meanstested pensions offered by the government. ${ }^{3}$

Once workers access their accounts, they can continue to work without making any additional contributions to the pension system. They also have a choice in the way in which they receive benefits - programmed withdrawals from the account, annuities or a combination of the two. Retirement benefits, regardless of their form of payment, are generally indexed to prices and include joint provisions to protect surviving spouses.

The private retirement account system is fully funded. However, the Chilean government diverts funds from general revenues to ensure a minimum retirement benefit level to individuals that reach the normal retirement age. This minimum benefit is roughly equal to 25 per cent of average wages - about 75 per cent of the minimum wage. These benefits are means-tested and require at least 20 years of contributions. ${ }^{4}$ For those with less than 20 years of contributions who are older than 65 , the Chilean government offers means-tested benefits equal to about half of the minimum retirement benefit.

The chaotic structure of the system was accompanied by growing deficits. Severe inflation and poor management depleted potentially large reserve accumulations. By the late 1970s, the Chilean system experienced annual deficits of nearly 3 per cent of GDP, and these deficits were projected to increase rapidly to more than 20 per cent by $2000 .^{8,9}$

Improving the traditional pension structure did not seem like a viable option, either politically or financially. Small patches would have increased the complexity of the system. The Chilean system faced enormous problems that demanded (and justified) radical changes that replaced the traditional — and increasingly unfair — system with one based on private retirement accounts.

\section{Paying for the transition}

Radical changes in retirement systems are likely to require large levels of funding to finance the transition. Contributions to private retirement accounts reduce the revenues available to pay for benefits promised by the traditional system, which imposes large fiscal demands, especially in the first years of the transition. In Chile, for example, the transition deficit neared 7 per cent of GDP per year during the first five years, slowly declining to its current level of about 3 per cent of GDP (see
Figure 1). Current estimates suggest that the transition deficit will fall to zero after $2030 .^{10,11}$

Fiscal discipline is the key to achieving a smooth transition. Governments have a limited array of options to use (tax increases, additional general revenue transfers, issue of debt and reduction of promised benefits). In Chile, the government employed a combination of tax increases, expenditure cuts and the sale of government-owned firms to generate significant surpluses in the nonsocial security part of the budget. By the early 1980s, the nonsocial security part of the budget enjoyed surpluses of more than 5 per cent of GDP. These surpluses financed most of the transition costs; debt instruments were used to a lesser extent. ${ }^{15,16}$ The Chilean case illustrates not only the importance and magnitude of transition costs, but also how sound fiscal policy can ensure a smooth transition to a new pension system.

\section{Development of capital markets}

The privatisation of the Chilean social security system was part of a set of economic reforms intended to modernise the economy, which included efforts to liberalise trade, regulate utilities, supervise the banking system, streamline labour market legislation and divest government 
assets. The overall success of these reforms made Chile the poster country of economic liberalisation, and its example was soon to be followed, at least partially, by other developing countries. ${ }^{17,18}$

Today, the significance of pension funds for the Chilean economy is indisputable. Figure 2 shows the extraordinary growth of total financial assets relative to GDP - most of which are held by pension funds. And although the pension reform was not the sole cause of the development of capital markets, the growth of private pension funds helped the modernisation effort, as it brought improved financial regulations, promoted innovation and increased corporate governance. ${ }^{19-21}$

For Chile, the introduction of private accounts helped to transform an incipient capital market into one where capital moves from savers to borrowers with few impediments, promoting higher growth and efficiency.

\section{The bad}

Despite the good effects for the Chilean economy, the new system still faces serious challenges, as some workers will reach retirement with low account accumulations, caused by a combination of deficient

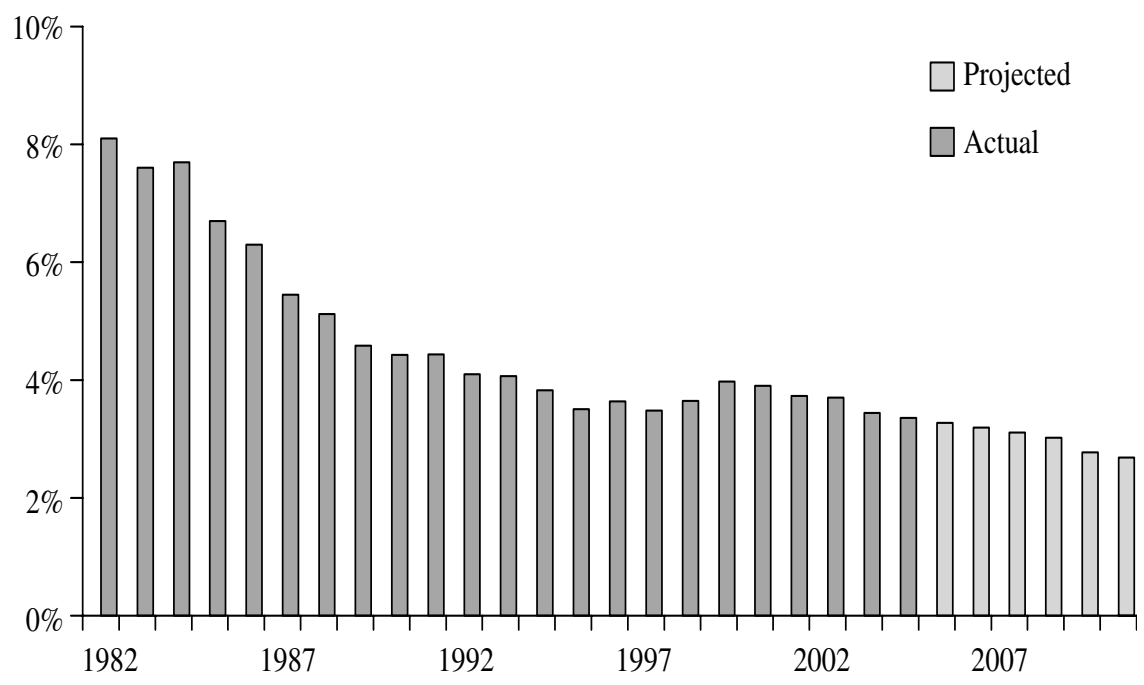

Figure 1: Transition deficit as a percentage of GDP, 1982-2010. Source: Author's calculations. ${ }^{12-14}$

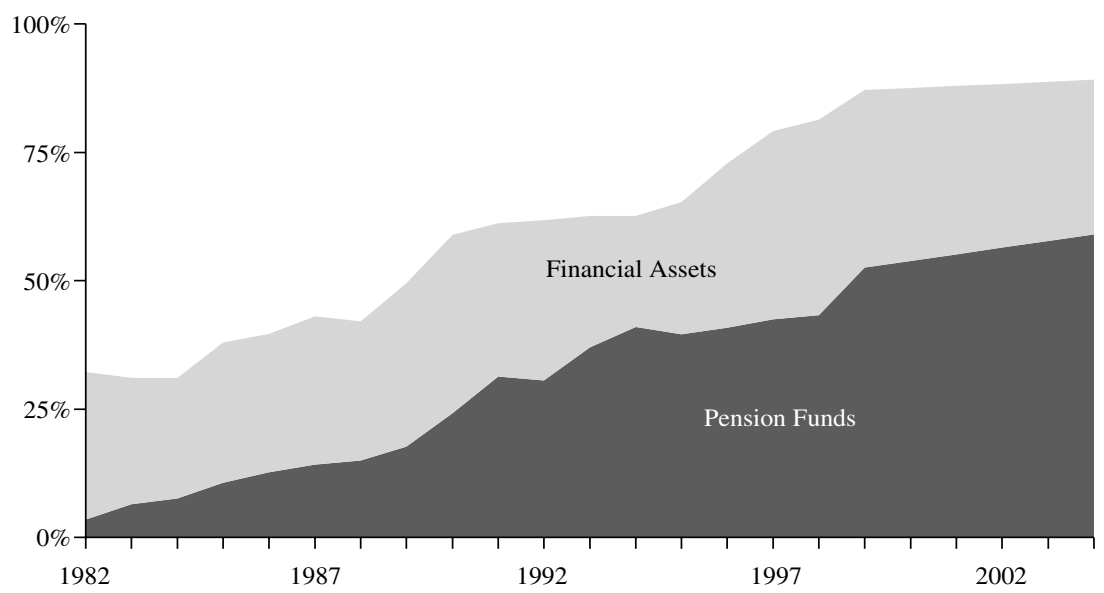

Figure 2: Financial instruments and pension funds as a percentage of GDP, 1982-2004.

Source: Author's calculations. ${ }^{22}$ 
and irregular pension coverage, and relatively high commissions and administrative fees.

\section{Private accounts do not provide universal coverage}

The traditional system provided retirement benefits for at least two-thirds of the workforce. ${ }^{23}$ When the private pension accounts were introduced, workers covered by traditional pension plans were given the option to join the new system, and 95 per cent of them did so. Since 1982, wage and salary workers have been required to join the private pension accounts, and self-employed individuals have participated on a voluntary basis. Today, almost the entire workforce has participated at some point in their career in the pension system by enrolling in one of the private investment firms that manage the private pension accounts. In 2003, however, the number of active participants - those who make contributions in any particular month to their private investment accounts - amounted to about 62 per cent of the labour force or 68 per cent of those employed, roughly equal to the participation rate of the traditional system. ${ }^{24-26}$ In contrasts, the US Social Security system covers about 96 per cent of its workforce. Figure 3 shows the historical trend of three different measures of pension coverage, all of which show only a slight increase during the last 15 years. ${ }^{27}$
The modest levels of active participation do not necessarily reflect a faulty system design. Instead, they are a consequence of the nature of the Chilean economy. For instance, the selfemployed represent about 30 per cent of total employment and are generally low-income, underground economy workers. Participation for self-employed individuals is voluntary, and more than 93 per cent of them do not contribute to the system. ${ }^{32}$ But coverage is not universal even among those who are not self-employed. The top line of Figure 3 shows that the percentage of wage and salary workers actively participating and contributing to the system is around 80 per cent.

The numbers for active participation shown in Figure 3 mean that, at any given point in time, about 40 per cent of workers are not contributing because they are unemployed or not complying with the law. The sporadic nature of the contributions calls into question the feasibility of 20 full years of contributions - the amount required to receive the minimum pension guarantee. ${ }^{33,34}$

\section{Commissions and administrative costs add up}

The Chilean experience with private pension accounts underlines the importance of administrative fees and commissions. Private account holders pay fees for starting up an

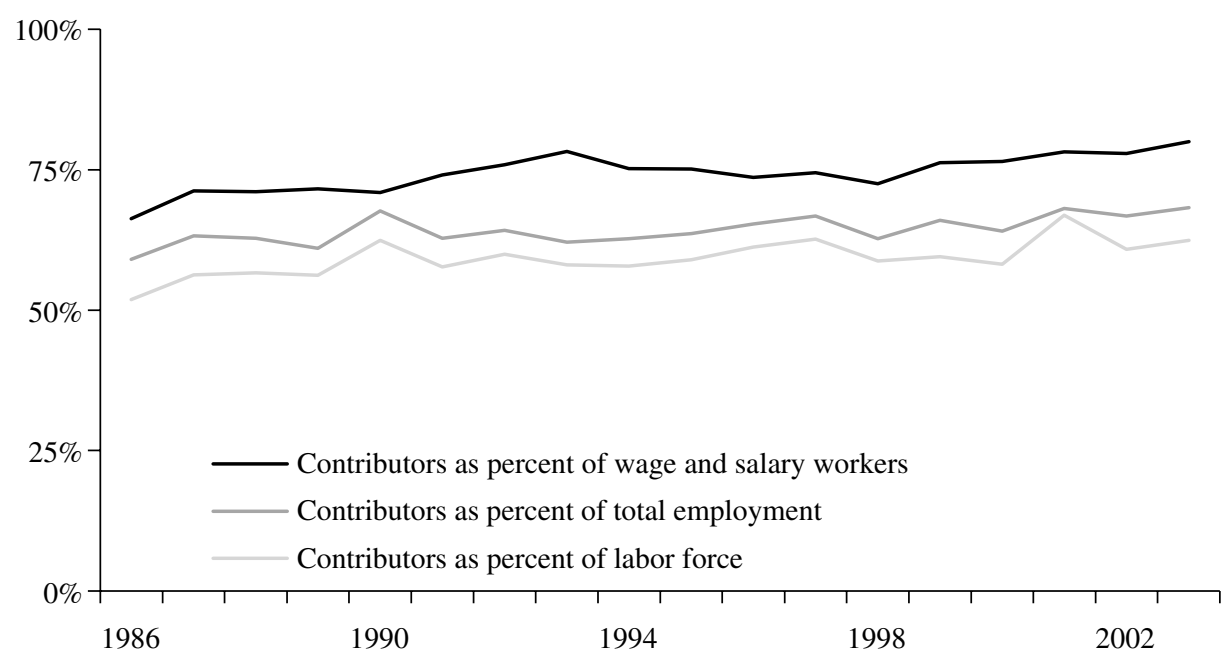

Figure 3: Measures of pension coverage, 1986-2003. Source: Author's calculations. ${ }^{28-31}$ 
account as well as proportional and flat commissions on contributions, which are intended to cover record-keeping and other administrative expenses. With each contribution, workers must also pay a premium for the disability and survivor insurance. ${ }^{35-38}$ Moreover, upon retirement, participants pay withdrawal commissions or annuity purchase fees, depending on the structure of benefits.

To illustrate the effects of commissions and administrative fees, consider an average worker who opts into the system in 1982 and retires in 2005. Every year, the worker contributes 10 per cent of earnings to his private retirement account and pays administrative fees and commissions.

(Disability and survivor insurance are excluded from this calculation.) The contribution net of fees and commissions then grows at the average rate of return realised by the pension funds each year - an outstanding 10.29 real return for this period. After 23 continuous years in the system, the individual retires.

Figure 4 shows the hypothetical account accumulation. At retirement, the individual will find that more than a fifth of the potential accumulation was diluted by administrative fees and commissions. With the remainder, the worker must then pay withdrawal fees or annuity purchase charges, which would reduce pension benefits further. ${ }^{40}$ After all these charges, the account balance would be able to generate an annuity of about 30 per cent of pre-retirement earnings. Comparatively, the Chilean system experienced much higher fees than those from the defined-contribution plan available to workers in the US federal government. ${ }^{41}$

Looking forward, the ability of the Chilean private accounts to provide retirement income adequately will depend on three main factors. First, the levels of administrative costs have been steadily declining, and some experts expect them to decline further (Figure 5). ${ }^{43}$ As a result, the burden of fees and commissions on current and future workers might be less severe. Secondly, the fortunately high rates of return on the accounts experienced during the 1983-2004 period are not sustainable in the long run, which will yield more modest account accumulations. And thirdly, the ability of workers to participate and make contributions into the system affects the retirement accumulation. The hypothetical case presented here included 23 years of continual employment. As the system matures, future retirees will have more years to build their private accounts. But the far-from-universal level of participation suggests that some workers will have significant periods with zero contributions

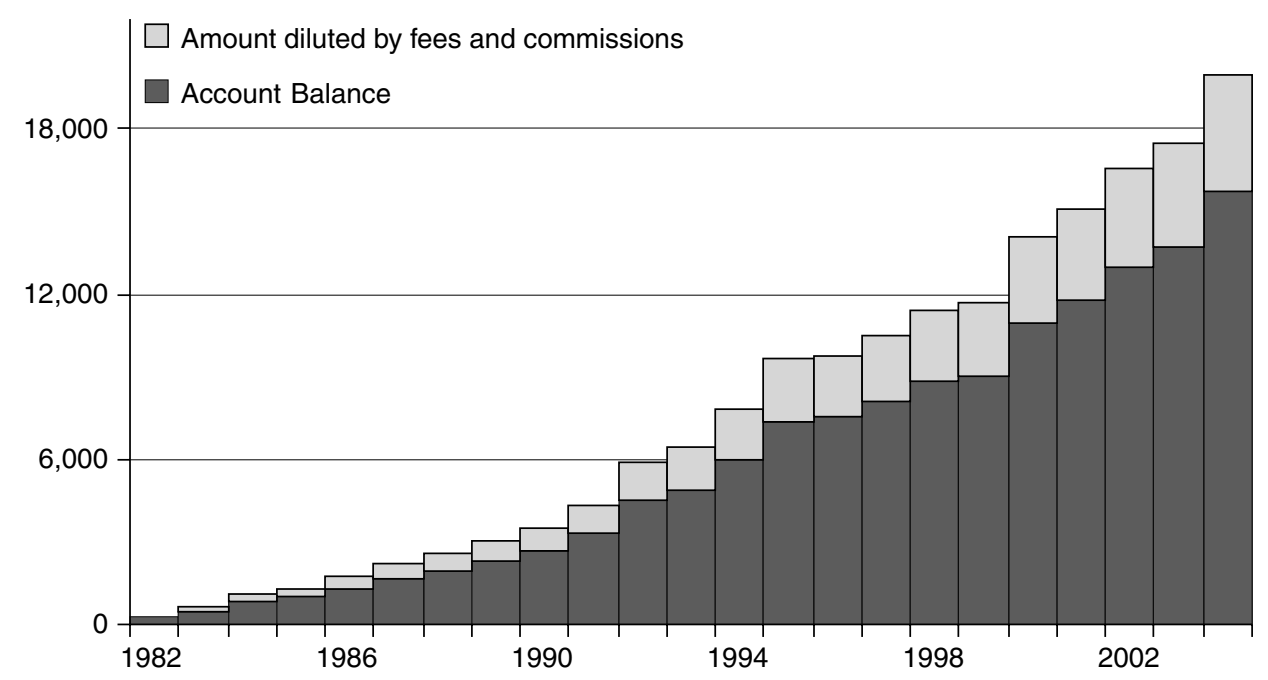

Figure 4: Evolution of a private retirement account for an average Chilean Worker, 1982-2004, 2004 Chilean Pesos Source: Author's calculations. ${ }^{39}$ 
because of unemployment spells or noncompliance.

\section{The in-between}

The Chilean system provides welfare benefits to those workers unable to accumulate enough in their accounts to meet their basic needs. This is a generous feature of the system that keeps most of the elderly in Chile out of poverty. Welfare benefits can, however, come with a high price tag to the taxpayers, and might create fiscal demands similar to those from pay-as-go systems. These welfare benefits can also introduce disincentives for workers, especially those with low incomes, to participate and comply with the system.

\section{Many depend on welfare}

The individual account system is successful, especially for those in the top of the income distribution. Low-income workers, on the other hand, might find that their private retirement accounts will not provide enough funds to keep them out of poverty. This makes them likely recipients of welfare, means-tested benefits, which are funded through general revenues. The existence of these welfare benefits is a generous feature of the Chilean system, which explains the low rates of poverty of older Chileans relative to the general population (Figure 6). ${ }^{44}$
Participating in the system might not be a good deal for low-income workers. The guaranteed pension benefit is about 75 per cent of the minimum wage. For minimum wage workers, reaching this level of income replacement will be almost impossible, even with a complete earnings history and full compliance in the system. This creates strong incentives to participate the minimum amount of years required to qualify for the guaranteed pension.

Currently, more than 11 per cent of participating retirees receive a minimum pension guarantee benefit, which costs about 0.1 per cent of GDP. As the system matures, the number of beneficiaries who will receive the minimum pension guarantee is predicted to rise to more than 30 per cent of participating retirees, as more workers will be unable to save enough in their own accounts by the time they reach retirement. The estimated costs of the minimum pension guarantee would be around 2.5 per cent of covered payroll (1 per cent of GDP). ${ }^{45-48}$ In addition to the fiscal burden of the minimum pension guarantee, general revenues are also used to fund the noncontributory pension assistance a small, means-tested pension for those who do not qualify for the minimum pension guarantee. The estimated costs of the noncontributory

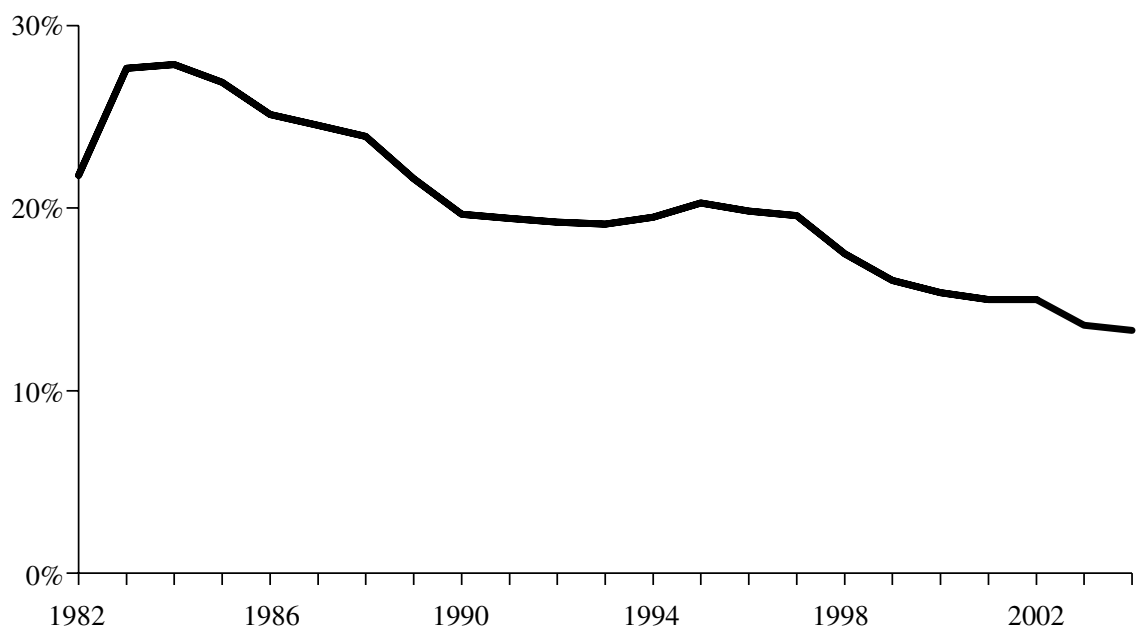

Figure 5: Administrative fees and commissions as percentage of total contributions, 1982-2004 Source: Author's calculations. ${ }^{42}$ 


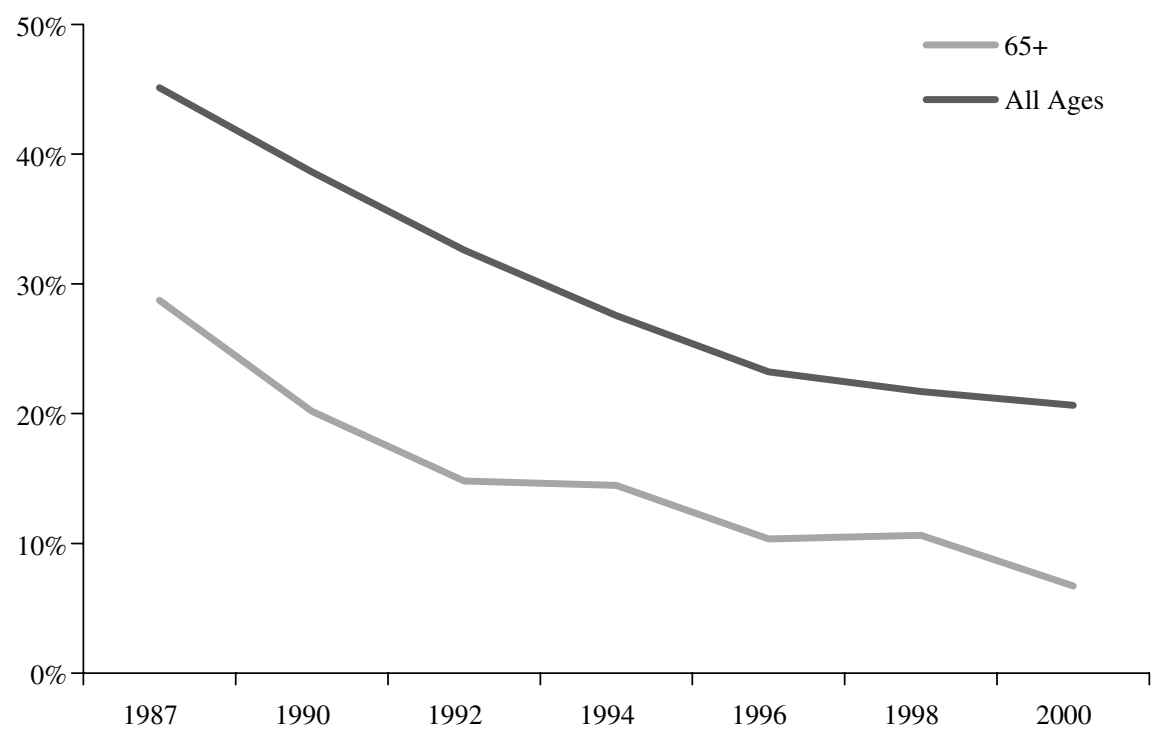

Figure 6: Poverty rates in Chile, 1986-2000.

Source: Ministerio de Planeación y Cooperación (2005) 'Distribución De La Población Por Año Según Tramo De Edad', retrieved 24th May, 2005, available at http://www.mideplan.cl/publico/casen.php?secid=4\&catid=20

pension assistance are projected to be about 0.5 per cent of GDP. ${ }^{49}$

\section{Conclusion}

A quarter of a century ago, Chileans embarked on a course of reform to modernise their economy. As part of these reforms, the Chilean government replaced the traditional pension system with one based on private retirement accounts. The radical reform, which brought dynamism to the Chilean economy, was a solution to the chaotic nature of the old system.

However, the system is not perfect. Various measures of pension coverage suggest that the system is far from universal; commissions, although declining, still eat a significant piece of the retirees' accounts; the amount of workers projected to depend on the minimum pension guarantee or the assistance pension raises concerns about the fiscal consequences of the system.

Care must be exercised when extrapolating from the Chilean experience to other countries. At the time of the reforms, Chile met a singular set of conditions: the Chilean markets were incipient; the pension system was chaotic and increasingly unfair and the non-pension part of the Chilean government ran surpluses. Other particularities of the Chilean case include the size of its informal economy, and the apparent acceptance of government-funded welfare programmes.

\section{Acknowledgments}

The author is grateful to Jamie Lee for excellent research assistance. The author also thanks Esteban Calvo and John Williamson for helpful comments on earlier drafts, and Peter Diamond, Alicia H. Munnell, Steven A. Sass and Salvador Valdés-Prieto for guidance and suggestions that significantly improved this paper.

\section{References and Notes}

1 Edwards, S. (1996) 'The Chilean pension reform: A pioneering program'. Working Paper 5811, National Bureau of Economic Research.

2 Before 2002, workers generally had no say on investment choices. Stringent government regulation resulted in competing pension funds with similar portfolio allocations, which generally included a large share of government bonds and other fixedincome securities. For a summary of recent changes to the Chilean system and detail about the current investment options, see Kritzer, B. (2002) 'Recent changes to the Chilean system of individual accounts', Social Security Bulletin, Vol. 64, No. 4. pp. 66-71.

3 Current Chilean law allows workers to access the funds in their private accounts if, after turning 55 , their balances are large enough to generate pension benefits greater than 50 per cent of the average of the last ten years of wages, and greater than 110 per cent of the welfare pension, and they have made at least 120 monthly contributions (ten years). These 
percentages are scheduled to increase to 70 and 150 per cent, respectively. See Superintendencia de Administradoras de Fondos de Pensiones (SAFP) (2005) 'Preguntas frecuentes sobre el sistema previsional chileno y el seguro de cesantía', Title XVII, retrieved 28th April, 2005, available at http://www.safp.cl/ preg_frecuentes/index.html.

4 Workers need to contribute at least 240 months to qualify for the minimum pension guarantee.

5 See Edwards, ref. 1 above.

6 Myers, R. J. (1996) 'Social security reform in Chile: Two views. An actuary's perspective', in Diamond, P. A., Lindeman, D. C. and Young, H. (eds.) 'Social Security: What Role for the Future?', National Academy of Social Insurance, Washington, DC.

7 Acuña, R. and Iglesias, A. (2001) 'Chile's pension reform after 20 years'. Social Protection Discussion Paper No. 0129, The World Bank.

8 Wagner, G. (1983) 'Estudio de la Reforma Previsional, Efectos en la Industria y en el País'. Working Paper, Institute of Economics, Catholic University of Chile.

9 Acuña and Iglesias, ref. 7 above.

10 Note that the transition deficit finances the (unfunded) benefits paid under the traditional system. See Valdés-Prieto, S. (2005) 'A Chilean economist's comment on Larry Rohter's reporting on Chilean Pensions appeared in the New York Times January 27, 2005', Unpublished Memo.

11 Spending associated with pensions, however, also includes the financing of the guaranteed minimum pension and the assistance (welfare) pension. See Williamson, J. B. (1999) 'Privatizing public pension systems: Lessons for the United States from Latin America'. Working Paper 1999-03, Center for Retirement Research at Boston College.

12 1981-1986: Acuña and Iglesias, ref. 7 above.

13 1987-2003: Author's calculations using data from the Central Bank of Chile (2005) 'Employment, wages, and demographics', Statistical Database, retrieved 24th May, 2005 available at http:// si2.bcentral.cl/Basededatoseconomicos/951_713.asp?cap $=040$.

14 2004-2010: Author's projections based on Arenas de Mesa, A. (2000) 'Proyecciones del déficit previsional chileno: Gasto público en pensiones asistenciales 1999-2010', in La política fiscal en América Latina. Una selección de temas y experiencias de fines y comienzos de siglo. Serie Seminarios y Conferencias, No. 03. CEPAL.

15 Diamond, P. A. (1996) 'Social security reform in Chile: Two views. An economist's perspective', in Diamond, P. A., Lindeman, D. C., and Young, H. (eds.) 'Social Security: What Role for the Future?', National Academy of Social Insurance, Washington, DC.

16 Acuña and Iglesias, ref. 7 above.

17 Peru, Argentina, Colombia, Uruguay, Mexico and Bolivia are among the more than 20 countries that have made similar reforms to their economies, see Asociación de Administradoras de Fondos de Pensiones (2005) 'Después de 24 años Chile continúa liderando reformas en materia provisional'. Serie de Estudios, No. 48.

18 For a general discussion of the Latin American reforms, see Devesa-Carpio, J. E. and Vidal-Meliá, C. (2002) 'The reformed pension systems in Latin America'. Social Protection Discussion Paper No. 0209, The World Bank.

19 Cifuentes, R., Desormeaux, J. and González, C. (2002) ‘Capital markets in Chile: From financial repression to financial deepening'. Economic Policy Papers, No. 4, Central Bank of Chile.
20 Walker, E. and Lefort, F. (2002) 'Pension reform and capital markets: Are there any (hard) links?'. Social Protection Discussion Paper, No. 0201, The World Bank.

21 Corbo, V. and Schmidt-Hebbel, K. (2003) 'Efectos macroeconómicos de la reforma de pensiones en Chile', in Resultados y desafios de las reformas a las pensiones, edited by Corporación de Investigación, Estudio y Desarrollo de la Seguridad Social (CIEDESS), Santiago.

22 Ferreiro, A., (ed.) (2003) 'The Chilean Pension System', Superintendencia de Administradoras de Fondos de Pensiones (SAFP), 4th edn, Santiago, Chile, available at http://www.safp.cl/ sischilpen/english.html; Superintendencia de Administradoras de Fondos de Pensiones (2005), E-mail to author concerning data on commissions, 1981-2004, March 22, 2005; and Central Bank of Chile (ref. 13 above). Financial Assets are M1-M7 as defined by Cifuentes, Desormeaux, and Gonzalez, ref. 19 above.

23 Acuña and Iglesias, ref. 7 above.

24 Data from Superintendencia de Administradoras de Fondos de Pensiones (SAFP) (2005) 'Series Estadísticas en Excel', retrieved 24th May , 2005 available at http://www.safp.cl/inf_estadistica/ index.html.

25 For comparable calculations, see Bravo, J. H. (2001) 'The Chilean pension system: A review of some remaining difficulties after 20 years of reform'. Discussion Paper, No.7, Project on Intergenerational Equity Institute of Economic Research, Hitotsubashi University.

26 These numbers are higher than those reported by Bravo, ref. 25 above for two reasons. First, Bravo does not include those covered by the traditional system, which underestimates actual pension coverage for the earlier years. And secondly, the 2000 figure from Bravo for 'contributors' shows a significant reduction from 1999 to 2000 that is not consistent with data from SAFP, ref. 22 above which indicate a 2 per cent increase in the number of 'contributors' between 1999 and 2000. Using the numbers from the SAFP, ref. 22 above, and excluding those covered by the traditional system, yields a coverage rate of 54.7 per cent for 2000 , which contrasts with the 46 per cent rate reported by Bravo.

27 An alternative is to measure pension coverage as the percentage of the population age 15 or older that contribute at any point in time, which produces significantly lower coverage rates. This measure, however, follows similar trends to the other series, showing a slight increase during the last 15 years. See Valdés-Prieto, S. (2004) 'Social security coverage in Chile, 1990-2001'. Background Paper For Regional Study On Social Security Reform, Office of the Chief Economist, Latin America and Caribbean Region, The World Bank.

28 Data from SAFP, ref. 22 above.

29 Instituto Nacional de Estadísticas (2005) 'Empleo Series', retrieved 24th May, 2005, available at http://www.ine.cl/03empleo/empleo.htm.

30 Instituto de Normalización Provisional (2003) 'Anuario Estadistico, 2003', retrieved May 24, 2005, available at http://tabancura.inp.cl/inicio/anuario/.

31 Central Bank of Chile, ref. 13 above.

32 Hypothetically, participation rates could be increased by extending the mandate to contribute to the self-employed. Politically, this option is not feasible. Asking the self-employed to contribute would affect those with very low earnings; enforcing the payments would be an immense challenge in the underground economy that already evades taxes. 
33 Current projections indicate that about 45 per cent of workers who contribute at some point in their work lives will not reach the 20 full years of contributions (240 months) requirement, and consequently, their pension benefits will be below the minimum pension guarantee. If the percentage of those who ever contributed is between 70 and 100 per cent of the workforce, then this means that between 45 and 60 per cent of the labour force will reach retirement with pensions lower than the minimum pension guarantee. See Berstein, S., Larrain, G. and Pino, F. (2005) 'Cobertura, densidad y pensiones en Chile: Proyecciones a 30 años plazo'. Working Paper, Superintendencia de Administradoras de Fondos de Pensiones, unpublished.

34 Given the contribution patterns, it might take up to 60 years for some workers to reach 20 full years of contributions. See Williamson, J. B. (2005) 'An update on Chile's experience with partial privatization and individual accounts'. AARP Public Policy Institute, \#2005-19, December.

35 See Asociación Internacional de Organismos de Supervisión de Fondos de Pension (AIOS)Berstein, S. Estudios y publicaciones: Boletines estadísticos 1999-2004', retrieved 24th May, 2005, available at http://www.aiosfp.org/pags/boletines.html.

36 Valdés-Prieto, ref. 10 above, International Federation of Pension Funds Administrators (FIAP) (2005) 'Statistics: historical series', retrieved 29th April, 2005, available at http://www.fiap.cl/p4_ fiap_eng/antialone.html?page=/p4_fiap_eng/site/edic/base/port/ series.html.

37 Schmidt-Hebbel, K. (1999) 'Chile's pension revolution coming of age', in Deutsches Institut furr Altersvorsorge (ed.) 'Reformerfahrungen im Ausland: Ein systematischer Vergleich aus sechs Laendern', Deutsches Institut für Altersvorsorge, Cologne.

38 As of 2004, disability and survivor insurance premiums represented 0.73 per cent of wages and 7.3 per cent of contributions (AOIS, ref. 35 above). Other sources estimate the combined premia at around 1 per cent of wages. See ValdésPrieto, ref. 10 above, and FIAP, ref. 36 above. AIOS, ref. 35 above provides detailed insurance premium data for 1997-2004. Prior to 1997, precise data on insurance premia are not easily available. Schmidt-Hebbel, ref. 37 above calculates premia for 1988-1997 by considering the total cost of insurance and the total income of contributors, although his figures for 1988 to 1990 seem unusually high. The calculations used on this paper use data from AIOS, ref. 35 above and Schmidt-Hebbel, ref. 37 above for 1991-2004. Earlier years are estimated by applying the average of the premium-to-commission ratio to the total commission for 1981-1991.

39 Based on data from SAFP, ref. 22 above; SAFP, ref. 24 above; Central Bank of Chile, ref. 13 above; FIAP, ref. 36 above; AIOS, ref. 35 above and Schmidt-Hebbel, ref. 37 above.

40 This calculation was performed using yearly data from 1982 to 2004 on the following variables in Chile: average taxable wage, average total commission and annual rate of return for pension funds. A worker making these wages who participated in the Chilean system from 1982 to 2005 would have 23.82 per cent of his total contributions eaten up by fees and commissions. Add on to this the withdrawal or annuity purchase charges paid at the time of retirement and the account shrinks even further. In the end, if the funds diverted to pay for fees and commissions would have been deposited into the worker's account, retirement benefits would be about 30 per cent higher.

41 For a comparison of administrative cost of private accounts, see Congressional Budget Office (2004) 'Administrative costs of private accounts in Social Security', March, 2004; and General Accounting Office (1999). 'Social Security reform:

Administrative costs for individual accounts depend on system design', GAO/HEHS-99-131.

42 Author's calculations based on data from SAFP, ref. 22 above; SAFP, ref. 24 above; Central Bank of Chile, ref. 13 above; FIAP, ref. 36 above; AIOS, ref. 35 above; Schmidt-Hebbel, ref. 37 above.

43 For 2004, the total commissions (fixed plus variable) averaged 1.54 per cent of earnings (13.31 per cent of contributions). Disability and insurance premia are an additional 0.73 per cent of wages (see ref. 32 above). Valdés-Prieto, ref. 10 above estimates the 'normal level' of commissions and fees around 9 per cent of contributions. The withdrawal fees were near 1.25 per cent and the annuity fee reached up to 6 per cent of the account value. See Central Bank of Chile, ref. 13 above and FIAP, ref. 36 above. It is expected that fees and commissions will continue to decline in the future for Chile as the system matures and benefits from economies of scale, see James, E., Smalhout, J. and Vittas, D. (2001) 'Administrative costs and the organization of individual retirement account systems: A comparative perspective', in Holzmann, R. and Stiglitz, J. (eds.) 'New Ideas About Old Age Security', World Bank, Washington, DC.

44 Valdés-Prieto, ref. 10 above.

45 For more details, see James, E., Martinez, G. and Iglesias, A. Postponed vs. early access to individual accounts and the fiscal implications of the minimum pension guarantee in Chile'. Unpublished Paper.

46 Williamson, ref. 11 above.

47 Asociación de Administradoras de Fondos de Pensiones (AAFP) (2004) 'Sistema de AFP: Mitos y realidades', August.

48 Superintendencia de Administradoras de Fondos de Pensiones, ref. 22 above.

49 AAFP, ref. 47 above and Centro de Estudios Nacionales de Desarrollo Alternativo (CENDA) (2004) 'Chile: Bases para una reforma del sistema de pensiones', Prepared by CENDA for the Instituto de Normalización Previsional (INP), Chile. 